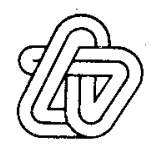

\title{
ARTES VISUALES
}

Revista trimestral, editada por el Museo de Arte Moderno, México

Redacción y Administración: Museo de Arte Moderno, Chapultepec c/o Carla Stellweg

Paseo de la Reforma y Gandhi

México 5, D.F., México

Precio por ejemplar:

México $\$ 25.00 \mathrm{MN}$, otros países de América: US $\$ 2.80$.

Suscripción anual (4 números):

México $\$ 90.00 \mathrm{MN}$, otros países de América: US \$12.00.

\section{ROMANICA}

Revista literaria en lenguas romance

publicada por New York University

\author{
Año XIII \\ dirigida por \\ Iraida Iturralde
}

Contiene monografías, reseñas de obras

literarias recientes, ensayos, poesía, cuento y drama.

Subscripción anual: $\quad 3$ dólares

Dirija toda su correspondencia a:

ROMANICA

822 Main Building

New York University

100 Washington Square East

New York, N. Y. 10003 


\section{BULLETIN HISPANIQUE}

Revue trimestrielle, organe des hispanistes français

ouvert à la collaboration étrangère

Comité Directeur:

Président: M. Bataillon, membre de l'Institut (Collège de France) Secrétaire-Gérant: N. Salomon (Faculté des Lettres de Bordeaux) Secrétaire-adjoint: M. Chevalier (Faculté des Lettres de Bordeaux)

Membres: Ch. V. Aubrun (Sorbonne)

P. Mérimée (Faculté des Lettres de Toulouse)

R. Ricard (Sorbonne)

A. Rumeau (Sorbonne)

et Le Directeur des Annales, Doyen de la Faculté des Lettres et Sciences Humaines de Bordeaux

Abonnements: France $\ldots \ldots \ldots, 60 \mathrm{~F}$.

Le montunt des abonnements, des demandes de numerós ou de tirages à part, les réclamations pour manques doivent être adressés à: Editions BIERE, 18 à 22, rue du Peugue, 33000 Bordeaux (C. C. P. Bordeaux 4388.38 S.)

The Official Quarterly of the American Association of Teachers of Spanish and Portuguese

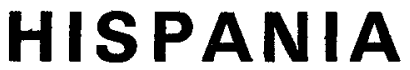

Published in March, May, September and December. Subscription, $\$ 10.00$ a year. For sample copies and information about subscription and membership in the Association, write to the Secretary-Treasurer, Richard B. Klein, Holy Cross College, Worcester, Mass. 01610.

Articles and news: Editor: Donald W. Bleznick, Romance Language Dept., University of Cincinnati, Cincinnati, Ohio 45221.

Books for review: Myron I. Lichtblau, Romance Language Dept., Syracuse Univ., Syracuse, N.Y. 13210.

Advertising rates: Albert Turner, Glenbrook South High School, 4000 West Lake Avenue, Glenview, Illinois 60025 . 


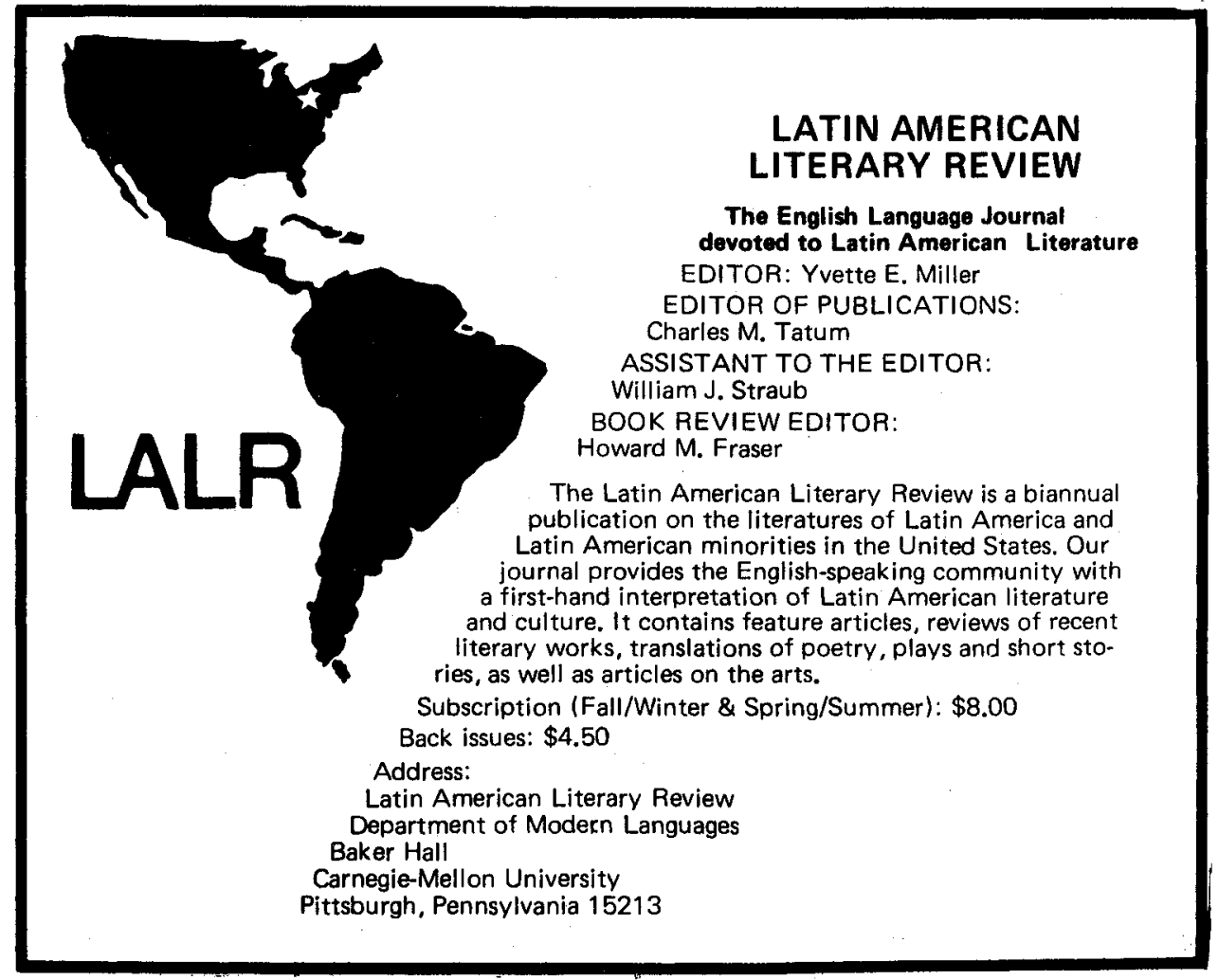




\section{H I S A M E R I C A \\ revista de literatura \\ Dirige: Saúl Sosnowski}

Sumario del no. 13:

Ensayos: Lucila I. Mena, "Cien años de soledad: Novela de La Violencia,".

Luis Leal, "Rafael Arévalo Martínez: Renovador y creador de formas literarias".

Roland Forgues, "Lectura de Los cachorros, de Mario Vargas Llosa".

Entrevista: Saúl Sosnowski entrevista a JULIO CORTAZAR.

Poesía: Textos de Cecilia Bustamante;

Javier Sologuren;

Hugo Diz.

Ficcion: Isaac Goldemberg, "El bautismo del cholo Marquitos Drasinover".

Amílcar Romero, "Contraindicaciones (antiácidos y efervescentes, refrescan la boca y apagan la sed)".

LEA EN EL PROXIMO NUMERO LAS BASES PARA EL CONCURSO DE CUENTOS QUE AUSPICIA HISPAMERICA

Suscripciones, colaboraciones, libros, correspondencia, a: Saúl Sosnowski, Hispamérica, 1402 Erskine Street, Takoma Park, Md. 20012, U.S.A.

Suscripciones: Individuales: US $\$ 10.00$; instituciones y bibliotecas: US $\$ 15.00$; patrocinadores: US $\$ 25.00$

TENEMOS NUMEROS ATRASADOS. Los suscriptores al año IV (1975) recibirán sin cargo adicional el anejo de $160 \mathrm{pp}$. sobre Literatura latinoamericana e ideología de la dependencia. Anuncios sobre el anejo de 1976 en el próximo número. 


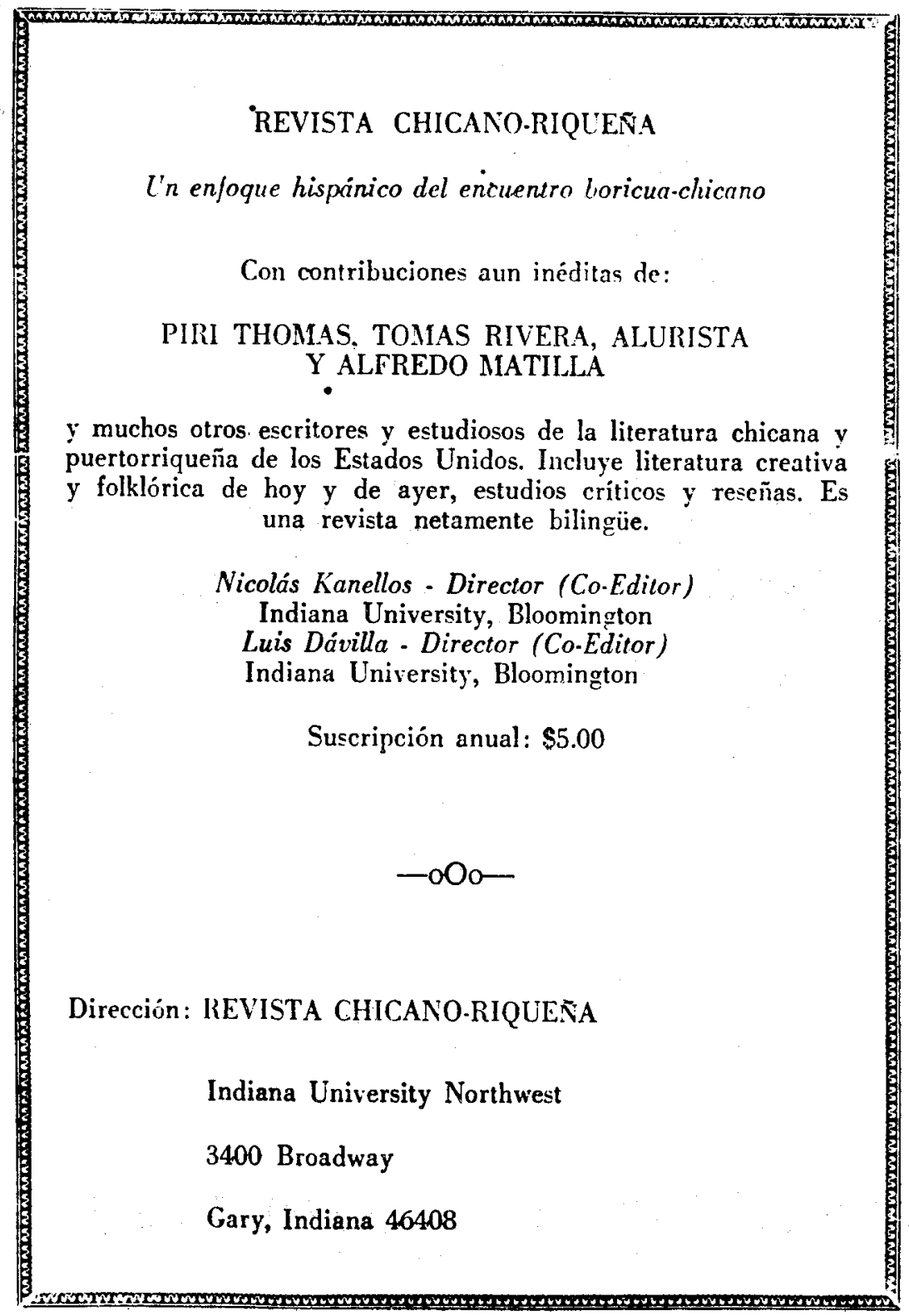




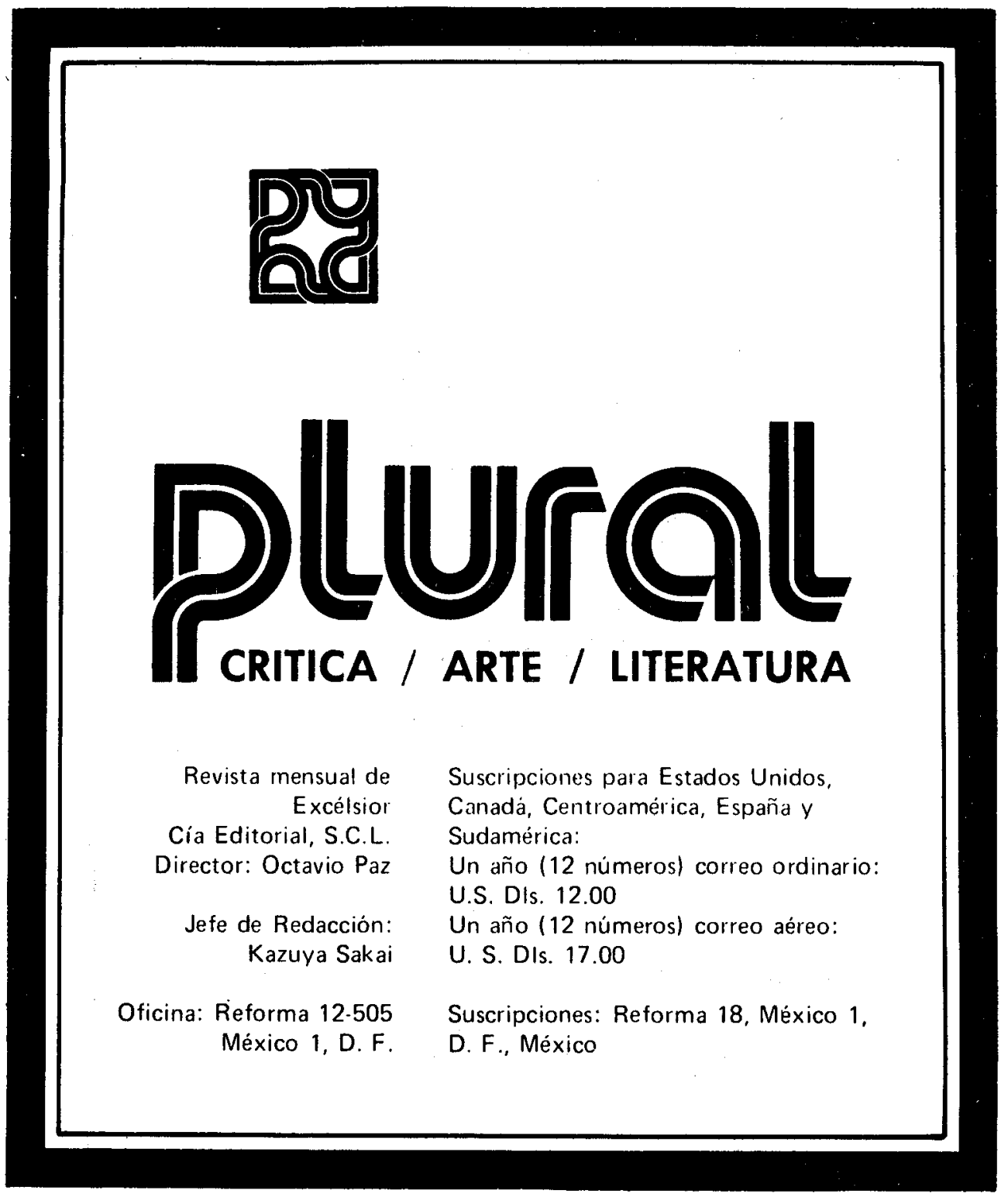




\section{CBA EDITORES}

\section{REVISTERO}

Todas las publicaciones periódicas de AMERICA LATINA fichadas, comentadas, con tarifas de suscripción, contenido y colaboradores.

Edición 1973: US $\$ 15.00$

\section{GUIA CBA 1973-74 DE LATINOAMERICA}

TODOS LOS DATOS DE REFERENCIA sobre todas las academias, asnciaciones, colegios, archivos, bibliotecas, universidades, institutos. deptos. experimentales, conservatorios, museos editores diarios, radios, televisiones, servicios universitarios, sociedades de estudio c investigación, etc. de TODA LATINOAMERICA.

350 pp. US $\$ 20.00$

PEDIDOS A: EDUARDO DARINO, EDITOR

GASILLA CORREO 1677. MONTEVIDEO URUGUAY.

NO ENVIE NUNCA CHEQUES A ESA DIRECCION, SALVO QUE SEA POR CORREO AEREO CERTIFICADO.

\section{SIN NOMBRE}

\section{REVISTA TRIMESTRAL LITERARIA}

Publicada por Editorial Sin Nombre, Inc.

Apartado 4391

San Juan, Puerto Rico 00905

Directora: Nilita Vientós Gastón

Vol. II, No. 4

(Homenaje a Baroja)

Vol. III, No. 1

(Homenaje a Neruda)

Suscripción anual ........... \$ $\$ 10.00$

Estudiantes Puerto Rico ........ $\quad 5.00$

Ejemplar suelto ............... $\quad 2.75$ 


\section{JOURNAL OF SPANISH STUDIES TWENTIETH CENTURY}

Editors: Vicente Cabrera and Luis González-del-Valle Assistant Editor: Bradley Shaw

Book Review Editor: Evelio Echevarria

Editorial Advisory Council: Jaime Alazraki, Fernando Alegría, Robert L. Bancroft, Mary Ann Beck, Harold L. Boudreau, Calvin Cannon, Rodolfo Cardona, Homero Castillo, Robert L. Coon, Ernesto Guerra Da Cal, Andrew P. Debicki, Kathleen M. Glenn, Antolín González-del-valle, Sumner Greenfield, Paul Ilie, Leon Livingstone, Juan Loveluck, Barnett A. McClendon, George McMurray, José Otero, Anthony M. Pasquariello, Hugo Rodríguez-Alcalá, Ivan A. Schulman, and Mario J. Valdés.

Some Published and Fortbcoming Articles: On Arrabal, Azorin, Borges, Cortázar, Donoso, Fuentes, García Pavón, Goytisolo, Gutiérrez Nájera, Hernández, Larreta, Lugones, A. Machado, Martín Santos, Rulfo, Salazar Bondy, Urbina, and Valle-Inclán.

Book Reviews: The Journal is publishing reviews of works within the fields of Spanish and Spanish American literatures in this century. The book reviews normally should be between 2 and 4 typewritten pages and may be written in English or Spanish. The original--with one copy--and return postage are requested. Book reviews, works to be reviewed and readers are welcome.

General Information: The Journal publishes scholarly articles dealing with the literatures of Spain and Spanish America in this century. The periodical appears three times annually (Spring, Fall, and Winter). Manuscripts are welcome. They should be between 12 and 25 typewritten pages and prepared in accordance with the $M L A$ style sheet all notes at the end. The original, an abstract, and one additional copy of both must be accompanied by return envelope and postage. Manuscripts may be written in English or Spanish. Subscription is $\$ 8$ per year ( $\$ 15$ for 2 years).

Address: Direct all manuscripts--studies and book reviews--to: Editors, Journal of Spanish Studies : Twentieth Ceniury, Department of Foreign Languages, Colorado State University, Fort Collins, Colorado 80521 U.S.A. Correspondence on subscriptions, advertisements and exchanges should be sent to: Editors Journal of Spanish Studies: Twentieth Century, Department of Modern Languages, Kansas State University, Eisenhower Hall, Manhattan, Kansas 66506 U.S.A. 


\section{A NUESTROS LECTORES \\ NUEVOS PRECIOS}

Desde hace cinco años no hemos variado el precio de la suscripción anual de la revista Cuadernos Americanos no obstante la constante elevación en los costos; pero como en los últimos meses han aumentado considerablemente el precio del papel y los gastos de impresión, cosa del dominio público, nos vemos obligados a establecer a partir de 1976, los precios que indicamos a continuación:

Dólares

$$
\text { Pesos }
$$

U.S.

México ............................ 175.00

Ejemplar suelto . . . . . . . . . . . . . . . . 35.00

América y España. . . . . . . . . . . . . . . . . . . 15.50

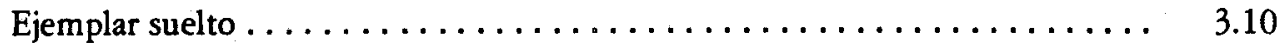

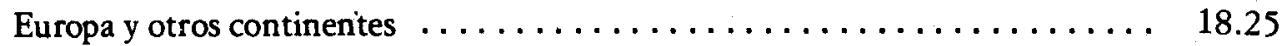

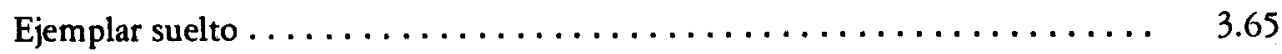

"CUADERNOS AMERICANOS",

Av. Coyocaán 1035

Apartado Postal 965

México 12, D.F.

México 1, D.F.

Tel.: $\quad 575-00-17$

todo el arte-teatro-cine-música-tv-escultura

de toda HISPANO-AMERICA en una sola revista bimensual

HISPANICAMERICAN ARTS

suscripción anual US\$8. (hispanoamérica \$5.)

el libro querido por los cineastas, necesitado por las bibliotecas:

\section{WORLD WIDE ENCICLOPEDIA OF FILM AWARDS}

todos los premios, de todo el mundo, a todas las películas: features, docurnentales, educativas, animación, científicas, tv, deportivas, etc. $\$ 6.50$

envie su orden y cheque a:EDUARDO DARINO - P.O. Box 5173 Grand Central Station New York, N.Y. 10017 USA.

En Sudamérica a: Eduardo Darino/Casilla correo 1677

Montevideo, URUGUAY, Sud América. 


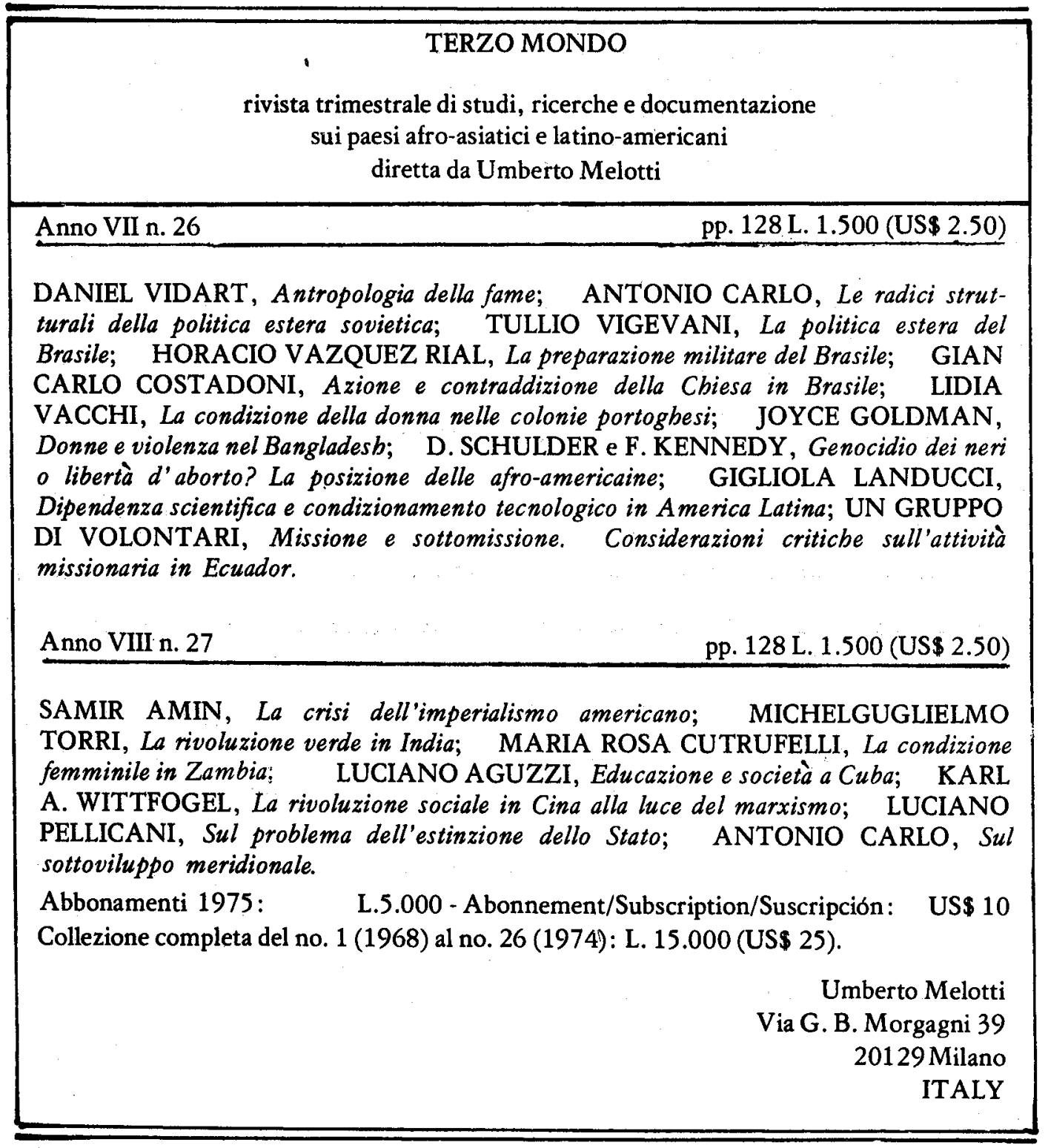




\section{MESTER}

\section{Revista de Literatura}

Dirección: Roberto Cantú

\begin{tabular}{lll}
\hline \hline Vol. V & Noviembre de 1974 & Núm. 1 \\
\hline \hline
\end{tabular}

INDICE: ESTUDIOS: Miguel Viñuela, "Un aspecto de la poesía de José Gorostiza"; Juan Rodríguez, "Acercamiento a cuatro relatos de. . Y Y nò se lo tragó la tierra"; Roberto Cantú, "Estructura y sentido de lo onírico en Bless me, Ultima"; Curtis Millner, "La isla de Juan Goytisolo: La vida como imposición"; Juan Villegas, "Tres dramaturgos en busca de universalidad: Buero Vallejo, Alfonso Sastre y Fernando Arrabal"'; Luis F. González-Cruz, "Virgilio Piñera y el teatro del absurdo en Cuba" ; Sharon Girard, "Venezuelan Cathedral Music".

ENTREVISTAS: Gary L. Brower, "Breves acotaciones para una bio-bibliografía de la 'vidobra' de Angel González"'; CUENTOS: Tomás Rivera, "Las salamandras"; Salvador Garmendia, "Caño Amarillo"; POESIA: Concha Zardoya, "El corazón y la sombra"; Saúl Yurkievich, "Maraña"; Luis F. Costa, "Amanece, retrocede"; René Acuña, "Domingo de ser solo", "Epistola a Felisa"'; Luis Comabella, "Una mañana de otoño"; RESEÑAS: Roland Hamilton, "Americanismos en la 'Historia' de Bernal Díaz del Castillo" (Manuel Alvar); Justo S. Alarcón, "Peregrinos de Aztlán”' (Miguel Méndez).

SUSCRIPCIONES: Número suelto: US\$3.00; suscripción anual: US\$6.00: Suscripción de estudiante: US\$4.00. Favor de enviar toda correspondencia (suscripciones, manuscritos, libros, etc.) a MESTER, Department of Spanish and Portuguese, University of California, Los Angeles, California, 90024, USA. 


\section{estudios \\ cubanos \\ cuban \\ studies}

Revista académica multidisciplinaria dedicada a Cuba

El volumen 6 (1976) se dedica por entero a:

CUBA: LA INSTITUCIONALIZACION DE LA REVOLUCION

El número de enero incluye artículos de Nelson P. Valdés, "Revolución e institucionalización"; Jorge I. Domínguez, "Institucionalización y las relaciones cívico-militares"; e Irving L. Horowitz, "Autenticidad y autonomía."

El número de julio incluirá artículos de Leonel A. de la Cuesta sobre la nueva Constitución, Edward González sobre el Congreso del Partido, y Marifeli Pérez-Stable sobre los sindicatos.

Ambos números tienen secciones sobre bibliografía clasificada, anotaciones de libros nuevos, e inventario de investigación en curso.

Números anteriores han incluído artículos de Ramón C. Barquín, "Cuba: La era cibernética," y de Lourdes Casal y Andrés R. Hernández, "Los cubanos en los EE.UU.: Un bosquejo de la literatura," además de ensayos bibliográficos sobre:

La mujer cubana en el siglo XX

La obra de Fidel Castro

Literatura creativa en la Isla y el Exilio

Lista clasificada de tesis doctorales

escritas en EE.UU. sobre Cuba

Lista de revistas y periódicos cubanos

Se publica semestralmente por el Centro de Estudios Latinoamericanos, Centro Universitario de Estudios Internacionales, Universidad de Pittsburgh, Pittsburgh, Pennsylvania 15260, EE.UU. Subscripción anual: $\$ 4$ si individual, $\$ 10$ si por instituciones. Números atrasados: $\$ 2.50$ individual, $\$ 5.50$ si por instituciones. 
THE BILINGUAL REVIEW/LA REVISTA BILINGUE

Dept. of Foreign Lang.

York College,

Jamaica, NY 11451

\begin{tabular}{lll}
\hline VOLUME II & JANUARY-AUGUST 1975 & NUMBERS 1 AND 2 \\
\hline
\end{tabular}

RESEARCH AND CRITICISM/INVESTIGACIONES Y CRITICA

Andrew D. Cohen, Bilingual Schooling and Spanish Language Maintenance: An

Experimental Analysis

Perry A. Zirkel, Bilingual Education Programs at the Elementary School

Level: Their Identification and Evaluation

David Lawton, Chicano Spanish: Some Sociolinguistic Considerations

A.M. Padilla and Ellen Liebman, Language Acquisition in the Bilingual Child

Paul H. Anisman, Some Aspects of Code Switching in New York Puerto Rican English

Gabriela Mora, Eugenio Maria de Hostos, El diario de un intimista

Francisco Jiménez, Dramatic Principles of the Teatro Campesino

MEASUREMENT AND EVALUATION/MEDIDA Y EVALUACION

Robert L. Politzer and Maryann McKay, A Pilot Study Concerning the Development of a Spanish/English Oral Proficiency Test

BIBLIOGRAPHY/BIBLIOGRAFIA

Howard Fraser, Languages in Contact: A Bibliographical Guide to Linguistic Borrowings Between English and Spanish

LITERATURE/LITERATURA

Alurista, Porque los vientos vuelan; Wild Butterflies

Juan Herrera, Cantos

J.S. Bernstein, Graphicures

Eduardo Ribera, A Little Lavabo

El Huitlacoche, Chuchu's Fontanel

REVIEW ARTICLES/RF.SEÑAS

Giorgio Perissinotto, Análisis contrastivo y enseñanza (Readings in SpanishEnglish Contrastive Linguistics, Rose Nash, ed.)

Gabriella de Beer, Ricardo Flores Magón and his Activities in the Chicano Community (Sembradores: Ricardo Flores Magón y el Partido Liberal Miexicano: A Eulogy and Critique, Juan Gómez-Quinones)

Diana Vélez, The Reality of the Chicanos ("...y no se lo trago la tierra"./ . "...and the earth did not part," Tomás Ribera)

Irwin Stern, Recent Luso-Brazilian Bilingual Editions

Karen S. Van Hooft, The United States Hispano Surfaces in an Elementary Spanish College Textbook (La lengua española: gramática y cultura, Matilde $O$. Castells and Harold E. Lionetti)

PROGRAMS AND RESOURCES/PROGRAMAS, E INFORMACION PROFESIONAL

Books, Journals and Textbooks Received

Professional Announcements 


\section{TRAVAUX DE L'INSTITUT D'ETUDES IBERIQUES \\ ET LATINO-AMERICAINES DE L'UNIVERSITE DES SCIENCES HUMAINES DE STRASBOURG}

22 , rue Descartes

67000 STRASBOURG

\section{T.I.L.A.S. XIII-XIV \\ 1973-1974 \\ SOMMAIRE}

\section{ARTICLES}

Erich KOHLER: Principes bistorico-sociologiques et science littéraire.

Catherine REDON-DAUER: Tradition et originalite dans les "Ficciones"' de J.L. Borges.

Simone VAUTHIER: Le Mexique et le mythe du voyage initiatique dans "On the road"', roman de Jack Kerouac.

Edelweis SERRA : Función criollista del mito en Leopoldo Marechal: El Viaje de la Primavera.

Claire PAILLER: La question d'amour dans le théâtre profane de Sor Juana Inés de la Cruz.

Marie-Claire BELTRANDO-PATIER: L'exotisme dans la musique française du $X$ VIIIe siècle: Les Indes Galantes de J. Pb. Rameau.

Maria Isaura PEREIRA DE QUEIROZ: Roger Bastide et les études sociologiques au Brésil.

Claudette CALLIER-BOISVERT: L'exode rural des femmes et leur fixation en milieu urbain: l'exemple de Recife:

II DOCUMENTS

Janny CHENU: Un projet créole de communication interocéanique à la veille de l'Independance (José Ignacio de Pombo et le progrès économique de la NouvelleGrenade.)

Eliane LAVAUD: Valle-Inclan y sus fuentes (El caso de una novela corta publicada en Méjico).

\section{POESIE}

André LABERTIT: Présentation d'un poète: Efrain BARQUERO.

\section{BIBLIOGRAPHIE}

JOSET Jacques: La littérature hispano-américaine (Francis Bezler)

GALARZA Joaquín: Lienzos de Cbiepetlán (Francis Bezler)

BAUDEZ Claude F. et BECQUELIN Pierre: Archéologie de Los Naranjos Honduras. (Francis Bezler)

DIAZ ROZZOTTO Jaime: Latein-Amerika: ein Kontinent wird geschmiedet. (Francis Bezler)

VIGGIANO ESAIN Julio: Cancionero popular de Cordoba. Poesia tradicional (coplas), tomo I. (Manuel Moya Trelles)

Libro de Cabildos de la Ciudad de Quito, 1650-1657. Vol. XXXIII. (Manuel Moya Trelles)

BONNEVILLE Henry: Le poète sévillan Juan de SALINAS (1562?-1643). Vie et oeuvre. (André Labertit) 


\section{$\sqrt{\frac{\mathbf{K}_{\mathbf{s}}}{\mathbf{s}}}$}

IMPORTANT

The publication of the series Biblioteca del Nuevo Mundo will continue in Pittsburgh under the same director (A. Roggiano) and printed by K\&S Enterprises. The latest volume hąs just appeared: Enrique Anderson Imbert, Estudios sobre Letras Hispánicas. 488 pages. $\$ 10.00$. To add this volume to your collection send check or money to:

$$
\begin{aligned}
& \text { Distribution Department } \\
& \text { 205 Iroquois Building } \\
& \text { 3600 Forbes Avenue } \\
& \text { P.O. Box } 7164 \\
& \text { Pittsburgh, PA. } 15213
\end{aligned}
$$

Postage is included on paid orders. A postage and handling charge of $\$ 1.50$ will be added to orders not accompanied by check or maney order.

\section{ATENCION}

La impresión de la serie Biblioteca del Nuevo Mundo continuará en Pittsburgh bajo la misma dirección (A. Roggiano) e impresa por la Empresa K\&S. El último volumen acaba de salir: Enrique Anderson Imbert, Estudios sobre Letras Hispanicas. 488 páginas. $\$ 10.00$ U.S. Para tener completa esta serie, favor de enviar su cheque o giro postal a :

$$
\begin{gathered}
\text { Distribution Department } \\
205 \text { Iroquois Building } \\
3600 \text { Forbes Avenue } \\
\text { P.O. Box } 7164 \\
\text { Pittsburgh, PA. } 15213 \\
\text { U.S.A. }
\end{gathered}
$$

El precio de $\$ 10.00$ U.S. incluye los gastos de franqueo si se trata de un pedido acompañado de un cheque o giro postal. En caso contrario, será necesario agregar $\$ 1.50$ U.S. para el franqueo. 


\title{
QUADERNI IBERO-AMERICANI
}

\author{
Revista de actualidad cultural de Espana, Portugal y \\ América Latina, fundada en 1946.
}

Director: Prof. GIOVANNI MARIA BERTINI de la Universidad de Turín (Italia). Secretario de Redacción: Giuliano SORIA.

En el número 42.44 dedicado a Nicaragua se publican textos inéditos de M. A. Asturias (Adiós a Neruda), de J. Guillén, P. A. Cuadra, J. Carrera Andrade y articulos de Ch. V. Aubrun, Rubió i Balaguer (cartas inéditas de R. Dario), G. Bellini, Zepeda Henriquez, E. Arellano y otros más.

Suscripción a un ciclo (4 números):

—España, Portugal y América Latina ........... 12 dólares

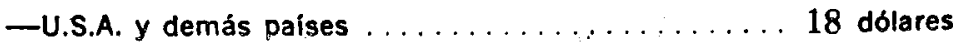

Dirección y Administración:

Quaderni Ibero-Americani, Via PO 19, TORINO (Italia).

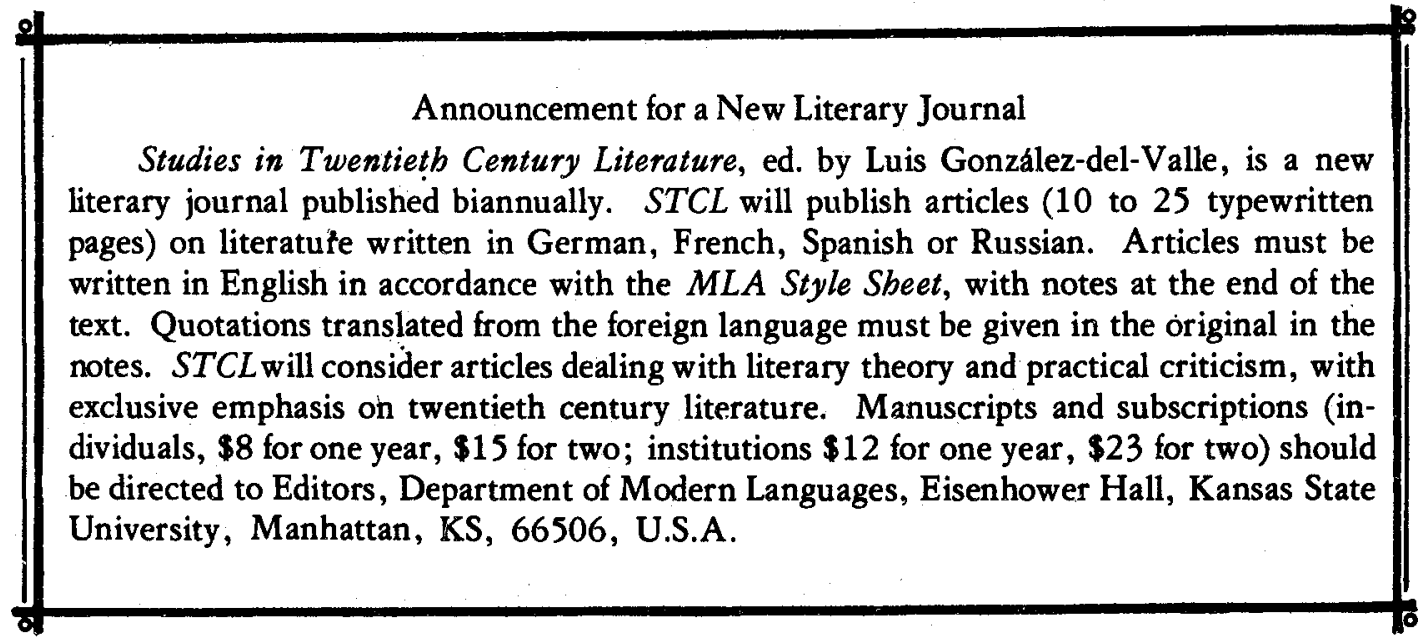




\section{DISPOSITIO}

(Revista Hispánica de Semiótica Literaria)

Director:

Walter Mignolo (University of Michigan)

Directores Asociados:

David Lagmanovich (Catholic University of America)

Saúl Sosnowski (University of Maryland)

Dispositio cubre aspectos teóricos y prácticos de la conceptualización del discurso, en especial del discurso "literario,"' y de la producción textual en lengua española.

Dispositio publicará, en el primer número, artículos de Enrique Ballón Aguirre (Universidad de San Marcos), Noé Jitrik (El Colegio de México), Silviano Santiago, Luiz Costa Lima (ambos de la Pontificia Universidade Católica do Rio de Janeiro), y John M. Lipski (Michigan State University). Además, textos de Hector Libertella, Tamara Kamenszain, y Osvlado Lamborghini.

El primer número aparece en Febrero 1976.

Manuscritos, publicidad, intercambio, suscripciones deben ser enviados a:

Dispositio

Department of Romance Languages

University of Michigan

Ann Arbor, Michigan 48104
Department of Romance Languages, The University of Michigan $y$ Sub-Stance, Inc. 
SALALM Secretariat

Benson Latin American Collection

The University of Texas at Austin

SRH 1-108

Austin, Texas 78712
TWENTY-SECOND SALALM

Gainesville, Florida

June 12-17, 1977

The University of Florida at Gainesville will be the site of the Twenty-Second Seminar on the Acquisition of Latin American Library Materials, June 12-17, 1977.

The theme of the Twenty Second Seminar will be "The Multifaceted Role of the Latin American Subject Specialist." A series of workshops, panels and roundtables will examine the multiple and diverse activities engaged in by present day subject or area specialists. These activities range from the selection of library materials in all formats through the technical procedures involved in acquiring the material, making it available to the public, to the provision of reference service and classroom instruction.

Specialists are also increasingly involved in negotiations with library and university administrations to increase or at least preserve funds for the purchase and processing of Latin American materials. Special sessions are planned on such topics as the preparation of bibliographies and reference guides, archival collections, and the ramifications of the political situations in Argentina, Peru and Chile for publishing activities. Book exhibits by a variety of North America, Latin American and European publishers are also planned. Tours of the University of Florida Library will be scheduled for interested participants.

The Seminars on the Acquisition of Latin American Library Materials have been sponsored since 1956 by the Organizatin of American States as an activity of its Inter-American Program of Library and Bibliographic Development and carried on informally by libraries and institutions interested in the procurement of Latin American materials. Togive the program of SALALM a firmer basis for carrying out its desired activities, SALALM was incorporated as a professional association in January 1968. The Secretariat is now located in the Benson Latin American Collection of the University of Texas at Austin, Texas.

Recent conferences were held in San Juan, Puerto Rico (1969); Toronto, Canada (1970); Puebla, Mexico (1971); Amherst, Massachusetts (1972); Port of Spain, Trinidad (1973); Austin, Texas (1974); Bogotá, Colombia (1975); and Bloomington, Indiana (1976). An increasing number of librarians, bibliographers, and bookmen from Latin America, the Caribbean, and Europe as well as from the United States and Canada have participated in the SALALM meetings and have contributed working papers and information, especially on publishing in Latin America and Latin American bibliography.

Registration for the Twenty-Second Seminar is $\$ 20.00$ for members and $\$ 30.00$ for nonmembers. Librarians and scholars from Latin America and the Caribbean may register without charge. Students from all areas will be admitted free to the conference but must register and pay a fee of $\$ 12.50$ if they wish sets of the preprinted papers and abstracts distributed at the meeting and the Final Report and Working Papers of the conference published afterward by the SALALM Secretariat. INVITATION AND REGISTRATION FORMS FOR THE TWENTY-SECOND SALALM WILL BE DISTRIBUTED SOON. Information on the content of the program and working papers may be procured from Mrs. Mary Magruder Brady, University of Saskatchewan Library, Saskatoon, Canada S7N OWO. News on local arrangements will be supplied by Rosa Q. Mesa, Latin American Documents, University of Florida Libraries, Gainesville, Florida, 32611. For other information refer to the Executive Secretary, Miss Lou Wetherbee, University of Texas at Austin, Benson Latin American Collection, Sid Richardson Hall 1-108, Austin, Texas, 78712 . 